IZA DP No. 6013

Why Ex(Im)porters Pay More:

Evidence from Matched Firm-Worker Panels

Pedro S. Martins

Luca David Opromolla

October 2011 


\title{
Why Ex(Im)porters Pay More: Evidence from Matched Firm-Worker Panels
}

\author{
Pedro S. Martins \\ Queen Mary University of London, \\ CEG-IST and IZA \\ Luca David Opromolla \\ Banco de Portugal \\ and UECE
}

Discussion Paper No. 6013

October 2011

\author{
IZA \\ P.O. Box 7240 \\ 53072 Bonn \\ Germany \\ Phone: +49-228-3894-0 \\ Fax: +49-228-3894-180 \\ E-mail: iza@iza.org
}

\begin{abstract}
Any opinions expressed here are those of the author(s) and not those of IZA. Research published in this series may include views on policy, but the institute itself takes no institutional policy positions.

The Institute for the Study of Labor (IZA) in Bonn is a local and virtual international research center and a place of communication between science, politics and business. IZA is an independent nonprofit organization supported by Deutsche Post Foundation. The center is associated with the University of Bonn and offers a stimulating research environment through its international network, workshops and conferences, data service, project support, research visits and doctoral program. IZA engages in (i) original and internationally competitive research in all fields of labor economics, (ii) development of policy concepts, and (iii) dissemination of research results and concepts to the interested public.
\end{abstract}

IZA Discussion Papers often represent preliminary work and are circulated to encourage discussion. Citation of such a paper should account for its provisional character. A revised version may be available directly from the author. 


\section{ABSTRACT \\ Why Ex(Im)porters Pay More: Evidence from Matched Firm-Worker Panels*}

We investigate the relationship between exporting, importing, and wage premia using a rich matched employer-employee data set. We improve on the previous literature (i) by using a new methodology to quantify the contribution of an extensive set of worker- and firm-level observable and unobservable characteristics to the wage gap, and (ii) by controlling for the import as well as the export activity of the firm. These two innovations allow us to avoid large biases that characterized the previous literature. A robust result is that the hiring policy of exporters is quite different than the one of importers. While firm size and sales are, to different extents, important components of the wage gap both for exporters and importers, importers hire workers that are overwhelmingly more able than the average. Workers at exporting firms, on the contrary, are no different in terms of unobserved time-invariant characteristics. Our analysis provides a useful guidance for recent theories that aim at explaining participation both in export and import markets and at including non-neoclassical labor market features into trade models.

JEL Classification: F16, J31, F15

Keywords: globalization, export, import, wage differentials

Corresponding author:

Luca David Opromolla

Departamento de Estudos Económicos

Banco de Portugal

Av. Almirante Reis, 71

1000 Lisboa

Portugal

E-mail: luca.opromolla@nyu.edu

\footnotetext{
* We thank Mário Centeno, Carl Davidson, Steve Matusz, Álvaro Novo, Gary Solon, Maurizio Zanardi and seminar participants at Banco de Portugal, ETSG (Rome), Michigan State University and Queen Mary, University of London for comments on an earlier version of the paper titled "Exports, Imports and Wages: Evidence from Matched Firm-Worker-Product Panels". We are especially grateful to Pedro Portugal for many thoughtful discussions, and to António Antunes and Lucena Vieira for computational assistance. The opinions expressed are those of the authors and not necessarily those of Banco de Portugal. Any errors are of our responsibility.
} 


\section{Introduction}

It is well established that exporting plants pay higher wages on average than nonexporting plants in the same industry (Bernard and Jensen, 1995, 1997). Mirroring this fact, recent advances in trade theory have gone in the direction of introducing features of non-neoclassical labor markets (e.g. search frictions, bargaining, rent-sharing, and efficiency wages) into trade models with heterogeneous firms based on Melitz (2003) or Bernard et al. (2003). Unlike their predecessors, these new models are consistent with the presence of wage inequality and, in particular, with the existence of a wage premia for exporting firms (e.g. Eaton et al. (2011). Helpman et al. (2011), Felbermayr et al. (2011), and Egger \& Kreickemeier (2009)). Despite the existing evidence, it is still however not clear why exporters pay higher wages. Many studies have taken advantage of the availability of increasingly rich data sets (in particular, matched employer-employee data) to estimate more and more demanding econometric specifications. They usually find two results. First, the unconditional exporter wage premium is quite large, usually in the order of 20 to 30 percent. Second, the premium lingers on after controlling for an impressive number of covariates, describing firms' and workers' observed characteristics or accounting for workers' and/or firms' fixed effects or even workerfirm spells. However, the remaining wage premium is usually very small, in the order of 2 to 3 percent, compared to the unconditional one and even in absolute terms. Moreover, there are at least two major flaws common to the previous literature. First, as pointed out by Gelbach (2010), the standard approach used to quantify the importance of each covariate (firms and workers observables and unobservables characteristics) in explaining the difference between the unconditional and conditional wage premium is seriously flawed. The standard practice of sequentially adding explanatory variables and interpreting the change in the coefficient of interest (i.e. the coefficient associated to being an exporter) as due to the introduction of the latest covariate is dependent on the arbitrary choice of the order of introduction of the covariates. Different orders deliver different results and none is, usually, free of biases. Second, most of the studies do not control for the import activity of the firms. Besides being of equal interest to study if there is a wage premium for importers, the fact that many exporters do also import introduces a bias in the estimation of the exporter wage gap. In this paper we deal with these two issues. The goal is to provide a cleaner comparison of the determinants of the wage gap of exporters and importers. Such an analysis can provide a useful guidance for 
developing theories that explain participation both in export and import markets. Overall, a robust result that emerges from this paper is that the hiring policy of exporters is quite different than the one of importers.

In this paper, we apply a new methodology proposed in Gelbach (2010) to a rich matched employer-employee data set, well-known for its wide coverage and high quality, to investigate the relationship between exporting, importing, and wage premia. We stress two main methodological contributions. First, we take into account the importing behavior of firms. We distinguish between firms that only export, firms that only imports, and firms that both exports and imports. Given that the export status of a firm is a good predictor of its import status Bernard \& Schott (2009), firm- or worker-level studies of the link between exports and wages that do not control for imports (e.g. Schank et al. (2007), Munch \& Skaksen (2008), Frias et al. (2009) ) may over- or underestimate the impact of exports $]^{1}$ Second, we use a simple methodology introduced in Gelbach (2010) to quantify the importance of firm's observed characteristics, and workers' observed and unobserved time-invariant characteristics in determining the exporters', importers, and exporters-importers' wage premia. The main advantage of this methodology is that it is not sensitive to the order of introduction of the covariates. As shown in Gelbach (2010), the strategy of sequentially adding covariates and interpreting the change in the coefficient of interest as associated to the introduction of each covariate is incorrect because results are sensitive to the order in which the covariates are introduced.

In the core of the paper we estimate two wage equations at the worker-level. The first ("base") model contains only a set of dummies for export-only, import-only, and exportimport firms, and delivers the a set of unconditional wage premia by trade status. We find that once export and import status are simultaneously controlled for, the unconditional wage

\footnotetext{
${ }^{1}$ More in general, there are many reasons why a partial refocusing on imports is needed. First, imports may matter more than exports in terms of their scope to affect welfare. As Krugman (1994) put it, '[T] he purpose of international trade - the reason it is useful - is to import, not to export. That is, what a country really gains from trade is the ability to import things it wants. Exports are not an objective in and of themselves.' Second, as the magnitude of imports is approximately equal to that of exports, imports clearly have a significant potential in terms of labor-market effects. Also, imports from developing countries have been regarded as a potentially major force driving the rising wage inequality observed in the U.S. and other countries (Freeman (1995) reviews this literature). This view stemmed from the factor price equalization result in international trade theory and the still large wage differences between developed and developing countries. Third, imports have recently been shown to generate important productivity effects, through channels involving learning, variety or quality aspects Amiti \& Konings (2007), Goldberg et al. (2008), Halpern et al. (2009). In this context, it is possible that the increased profits resulting from the purchase of (higher-quality) intermediate inputs from foreign manufacturers be eventually shared with the firm's workers in terms of wages that exceed those workers' outside options. Such rent sharing would conceivably occur in labor markets that exhibit non-competitive features.
} 
premium paid by export-only firms becomes quite small (3.5 percent), as compared to the previous literature, while both the wage gap paid by firms that only imports and the one paid by exporter-importers is very large (23.9 and 29.1 percent, respectively). As mentioned above, the export status of a firm is a good predictor of its import status Bernard \& Schott (2009), implying that studies that do not control for imports may overestimate the impact of exports. The second ("full") model encompasses the "base" model and extends it by considering a large set of worker-level and firm-level observable characteristics as well as worker fixed effects. Our estimates confirm and, to some extent, reinforce a tendency seen in the previous literature: the introduction of firms' and workers' controls explain the almost totality of the unconditional wage premium.

Our main results though come from the application of the Gelbach (2010) methodology to the "base" and "full" model. The decomposition reveals that the wage premium for workers employed by firms that only export is associated to firms' and workers' characteristics that are very different from those associated to the wage premium paid by firms that also imports. Export-only firms pay higher wages mainly because they have a bigger workforce and sell more. Their workers are not, generally, "better" or "more able" than average. Firms that also imports (imports-only or exporters-importers) also pay higher wages because they are bigger and sell more but these factors definitely play a less important role. On the contrary, these firms, and among these especially those that only imports, decisively employ "better" or "more able" workers. More specifically, in the case of export-only firms, firm-level observables (size, total sales, number of plants, and firm age) account for 80 percent of the wage gap, with the main role played by firm size (32 percent) and firm total sales (40 percent). Worker fixed effects, capturing all the time-invariant unobserved workers' characteristics, have a limited and negative impact on the exporter wage gap (2 percent). The picture is quite different for importers. Firm-level observables are still important but only account for 30 percent of the wage gap, with the main role played again by firm size (12 percent) and firm total sales (17 percent). The striking difference lies in the role played by workers' (time-invariant) unobserved characteristics: worker fixed effects account for a whopping 66 percent of the wage gap. The sign is positive: the wage bill of importers is higher because workers are, on average, much more able.

Recently, a number of papers have extended the two main models of trade with heteroge- 
neous firms to allow for a more realistic description of the labor market. Our results can be interpreted as a first test for these recent studies. In Eaton et al. (2011), wages, set through bargaining, are an increasing function of the productivity of the firm. More productive firms are also those that enter more markets and sell more in each market and enter less popular markets. Our results are consistent with Eaton et al. (2011) in the sense that we do find that firms' productivity is positively associated with a wage premium for exporters. Helpman et al. (2011) propose a model where more productive firms have large revenues, match with more workers, and screen to higher ability thresholds. As a result they have workforces of higher average ability and pay higher wages. While we also find that firm's size and sales are positively correlated with a wage premium for exporters, we do not find that exporters hire workers that are, on average, more able. Actually, the workers fixed effects in our wage regressions play almost no role in explaining the exporters' wage premium. On the contrary, we find that importers definitely hire workers that have better unobserved time-invariant characteristics. In this respect, our results suggest that the channel suggested by Helpman et al. (2011) seems more adequate to explain the behavior of importers.

The spirit of our paper is close to the one of Moxnes et al. (2010). They pose the question if exporters are more productive than nonexporters because of differences in firms' intrinsic efficiencies or because of differences in the composition of the workforce. They find that augmented measures of total factor productivity which take worker characteristics into account, indicate that 15-40 percent of the exporter premium reflects differences in workforce rather than true efficiency. Exporters typically employ workers with longer tenure, more experience and higher education than the average non-exporter. There are two main differences between Moxnes et al. (2010) and our paper. First, their focus is on explaining the exporters' productivity premium while our focus is on explaining the wage premium of both exporters and importers and, in particular, in assessing the relative importance of firm characteristics, workers' observed characteristics, and workers' unobserved characteristics. We employ a new methodology that allows us to determine the importance of each of the above factors independently from the order of introduction into the wage equation. Second, even if Moxnes et al. (2010) control for workers' unobserved time-invariant characteristics in estimating a Mincerian wage equation they do not focus on the differences between exporters and nonexporters in terms of workers' unobserved characteristics. 
Finally, there has been, in the recent literature, a small surge of papers interested in the effect of importing on firm productivity, employment and wages. To begin with, exporters are frequently importers as well Bernard \& Schott (2009), in which case part of the productivity advantage of exporters can be due to their sourcing inputs from foreign markets Altomonte \& Bekes (2009). In any case, either that of importers only or exporter-importers, access to cheaper imported inputs can again raise productivity via learning, variety, and quality effects.22 Importers arguably have greater choice in the sourcing of their inputs and can exploit any gaps between international and national prices, resulting in productivity or cost-efficiency differences. A recent literature has focused on the effects of outsourcing and offshoring Kramarz (2008), Hummels et al. (2010), Mitra \& Ranjan (2010), two forces which can be important components of firm-level imports. Their emergence in the last decade has prompted concerns that the previous consensus of a relatively unimportant effect of international trade (and imports in particular) on wages may no longer apply Krugman (2008).

The remaining of the paper is as follows: Section 2 presents the two data sets used and several descriptive statistics. Section 3 describes the methodology used to quantify the determinants of the wage gap by firm trade status and shows, by means of a simple example, why the standard sequential approach leads to biased results. Section 4 presents our main results and, finally, Section 5 concludes. In the Appendix we provide further details on the data used and summarize the theoretical linkages between exporting, importing, and wages.

\section{The matched employer-employee and customs trade data}

The data used in this paper are obtained from merging two major data sets: the INE trade data and the QP labor data. The INE trade data includes all export and import transactions by firms that are located in Portugal, on a monthly basis. These data are derived from customs returns forms in the case of extra-EU trade and from a special form supplied to the Portuguese statistics agency, INE - Instituto Nacional de Estatística, in the case of intraEU trade (Intrastat). Overall, the data amount to the official total exports and imports of Portugal.

Each transaction record includes the firms tax identifier, an eight-digit Combined Nomenclature product code, the value of the transaction, the quantity of transacted goods, the

\footnotetext{
${ }^{2}$ See Amiti \& Konings (2007), Kasahara \& Rodrigue (2008), Goldberg et al. (2008), Halpern et al. (2009).
} 
destination/origin country, the relevant international commercial term, etc. We were able to gain access to data from 1995 to 2005 for the purpose of this research.

The second main data source is Quadros de Pessoal (QP), a longitudinal dataset matching all firms and workers based in Portugal. The data are made available by the Ministry of Labor and Social Security, drawing on a compulsory annual census of all firms in Portugal that employ at least one worker. Indeed, each year every establishment with wage earners is legally obliged to fill in a standardized questionnaire. Reported data cover the establishment itself, the firm and each of its workers. The variables available in the data set include the firm's location, industry, total employment, sales, ownership structure (domestic private, public or foreign), and legal setting. The individual data cover information on all personnel working for each firm in a reference month (October), except for 2001. They include information on gender, age, occupation, schooling, hiring date, earnings, duration of work, etc. The information on earnings is very complete. It includes the base wage (gross pay for normal hours of work), seniority payments, regular benefits, irregular benefits and overtime pay.

Each firm entering the database is assigned a unique, time-invariant identifying number which we use to follow firms over time. The Ministry of labor and Social Security implements several checks to ensure that a firm that has already reported to the database is not assigned a different identification number. Similarly, each worker also has a unique identifier, based on the worker's social security number, which we use to follow individuals over time. The administrative nature of the data and their public availability at the workplace - as required by the law - imply a high degree of coverage and reliability. The public availability requirement facilitates the work of the services of the Ministry of Employment that monitor the compliance of firms with the law (e.g., illegal work) $!^{3}$

Finally, we merged the two data sets using the firm identifiers and firm characteristics available in each data set. Given the predominance of manufacturing in international trade, we excluded from our analysis non-manufacturing sector firms 4 We restrict the sample to

\footnotetext{
${ }^{3}$ The same data set has been used by, amongst others, Cabral \& Mata (2003) to study the evolution of the firm size distribution; by Blanchard \& Portugal (2001) to compare the U.S. and Portuguese labor markets in terms of unemployment duration and worker flows; by Cardoso \& Portugal (2005) to study the determinants of both the contractual wage and the wage cushion (difference between contractual and actual wages); by Martins (2009) to study the effect of employment protection on worker flows and firm performance. See these papers also for a description of the Portuguese labor market.

${ }^{4}$ See Amador \& Opromolla (2008) for more information about the data and several additional descriptive statistics. In particular, Amador \& Opromolla (2008) shows that in 2005 about 19 percent of Portuguese exports belong to "Machinery, electrical equipment", 14 percent to "Vehicles, aircraft, vessels", 13 percent to "Textiles", 8 percent to "Base metals", 6 percent to "Mineral products", and 5 percent to "Chemical products", "Plastics and rubber", "Prepared food, beverages, tobacco" each.
} 
include only firms based in Continental Portugal and their full-time employees, age between 16 and 65 , working a minimum of 25 and a maximum of 80 total hours per week. In the final data set used for wage regressions the total number of firms (traders and non-traders) by year ranges from 18,288 in 1995 to 29,458 in 2005 , while the total number of employees varies from 636,690 in 1995 to 626,216 in 2005, yielding a minimum (across specifications) of 4,272,213 person-years. More interestingly, slightly more than one in five manufacturing firms (32 percent in 1995 and 25 percent in 2005) is engaged in foreign markets either as exporter or as importer (or as both). For comparison, Bernard \& Jensen (1995) report for U.S. manufacturing plants in 1987 that 15 percent export; Eaton et al. (2004) report that 17 percent of French manufacturing firms export in 1986, and Irarrazabal et al. (2010) report that about 40 percent of Norwegian manufacturing firms are exporters.

The percentage of firms engaged in international markets can be decomposed according to the mode of participation: about 7.4 percent of all firms are exporters-only, 6.5 percent are importers-only and 11.1 percent are exporters-importers in 2005. Again, for comparisons, Muuls \& Pisu (2009) report that the corresponding percentages for Belgian firms are 4.3, 8.0 and 10.7 respectively. In terms of sales, exports correspond, in 2005, to approximately 29 percent of total sales of the manufacturing sector, while imports correspond to about 23 percent of the same total sales $5^{5}$

\subsection{Descriptive statistics}

The special characteristics of traders can be discerned more clearly from Table 1, which presents several statistics from pooled 1995-2005 data, by firm international trade status (non trader, exporter-only, importer-only and exporter-importer). Table 1 presents statistics on firm-level and worker-level variables used in our estimations and referring to observations for which all covariates used in the econometric analysis of Section 4 are jointly available. Panel A reports statistics on variables measured at the firm level while Panel B present variables measured at the worker level. We find that mean sales and mean size are much higher in the case of traders than non-traders (1336 thousands euros or more vs 508 thousands euros; 26 workers or more vs. 13 workers); among traders, firms that both import and export are the biggest both in terms of total sales and in terms of number of workers (12.8 million euros and more than 111 workers), followed by importers-only (3.3m euros and 35 workers) and

\footnotetext{
${ }^{5}$ Additional information on the two data sets and the variables used can be found in Appendices A and B.
} 
exporters-only (508 thousands euros and 13 workers). Mean firm size (in terms of number of workers) is much higher in the case of traders although less than proportionately in terms of the sales gap, suggesting greater productivity amongst traders ${ }^{6}$ Firms that trade in foreign markets, (i) are more likely to be foreign-owned, (ii) are older, and (iii) have more plants than those firms that nor import neither export.

There are not major differences across firm types in terms of the schooling, experience, or average hours worked of their employees; however, workers in firms that trade tend to exhibit higher levels of tenure and exporters-only employ a more feminine workforce 7 Furthermore, of particular interest for our study, we find that hourly wages are considerably higher at firms that trade than in firms that only sell at the domestic market: in the latter case the average real hourly wage is 3.64 euros per hour, while exporters-only (importers-only) pay 3.76 euros per hour (4.86 euros per hour) and exporter-importers pay 5.12 euros per hour. Similar comparisons arise from the analysis of medians instead of means.

Table 1 also makes clear the potential economy-level effects from the wage practices of firms that trade as they account for a large proportion of the manufacturing workforce: more than 3 millions workers-year were employed by firms that export and/or import, compared to about 1.2 millions in the case of manufacturing-sector firms that do not trade.

\section{Decomposing the wage premia}

In this Section we review the methodology introduced by Gelbach $(2010)$ by presenting a simplified version of the econometric specification adopted in the analysis performed in Section 4. The objective pursued in Section 4 is to study how the exporter, importer, and exporterimporter unconditional wage premia change when one includes additional covariates in the econometric model, like worker- and firm-level observables or worker-level (time-invariant) unobservables. The methodology proposed by Gelbach (2010) allows to quantify the contribution of each of these additional covariates independently from the order in which covariates are partialled out. As a consequence, the common practice of sequentially adding covariates and interpreting the change in the coefficient of the variable of interest (i.e., in our case, the coefficients associated to being an exporter or an importer) as due to the introduction of the

\footnotetext{
${ }^{6}$ Starting from Melitz (2003), many trade models with heterogeneous firms and fixed costs of exporting show that the most productive and bigger firms self-select into export markets.

${ }^{7}$ Using a a Danish matched worker-firm data set, Munch \& Skaksen (2008) find that firms with high export intensities have longer job tenure.
} 
last covariate is not correct and can lead to large biases. Consider a linear population model with two sets of covariates, $X_{1}$ and $X_{2}$,

$$
Y=X_{1} \beta_{1}+X_{2} \psi_{1}+\epsilon_{1}=\alpha_{1}+\tilde{X} \beta_{1}^{\tilde{X}}+\tilde{M} \psi_{1}^{\tilde{M}}+S \psi_{1}^{S}+\epsilon_{1}
$$

In our example, $Y$ is the (log real) wage of a worker. $X_{1}$ includes a constant, and one dummy variable equal to one if the firm that employs the worker is exporting $(\tilde{X}) . X_{2}$ contains instead another dummy variable equal to one if the firm is importing $(\tilde{M})$, and firm size (log of the number of employees), $S$. We consider, in this example, the importer dummy and firm size for the following reasons. The export status of a firm is a good predictor of its import status Bernard \& Schott (2009), implying that firm- or worker-level studies of the link between exports and wages that do not control for imports Schank et al. (2007), Munch \& Skaksen (2008), Frias et al. (2009) may over- or underestimate the impact of exports. Firm size is well-known to be positively related to wages and to firms' trade participation. The exporter unconditional wage premium is found by including only $X_{1}$ among the covariates,

$$
Y=\alpha_{2}+\tilde{X} \beta_{2}^{\tilde{X}}+\epsilon_{2}
$$

The well-known omitted variable bias formula tells us that if there is a correlation between the exporter status and one or more of the covariates in $X_{2}$ and these have an effect of their own on wages (i.e. $\psi_{1} \neq \mathbf{0}$ ) then dropping $X_{2}$ introduces a bias, $\delta$, on the coefficient of $X_{1}$, the exporter conditional wage premium. In population terms,

$$
\beta_{2}=\beta_{1}+\left(X_{1}^{\prime} X_{1}\right)^{-1} X_{1}^{\prime} X_{2} \psi_{1}=\beta_{1}+\Gamma \psi_{1}=\beta_{1}+\delta
$$

where $\Gamma$ is the matrix of coefficients from projecting the columns of $X_{2}$ on the columns of $X_{1}$,

$$
X_{2}=X_{1} \Gamma+\varepsilon
$$

or, in more detailed form,

$$
\begin{gathered}
\tilde{M}=\Gamma_{0}^{\tilde{M}}+\tilde{X} \Gamma_{\tilde{X}}^{\tilde{M}}+\varepsilon^{\tilde{M}} \\
S=\Gamma_{0}^{S}+\tilde{X} \Gamma_{\tilde{X}}^{S}+\varepsilon^{S}
\end{gathered}
$$


where $\tilde{M}$, and $S$, as explained above, are the columns of $X_{2} . \Gamma_{\tilde{X}}^{S}$ tells us the difference between the mean size (after partialling out the other elements of $X_{1}$ ) of firms that export and the mean size of all other firms. Similarly, $\Gamma_{\tilde{X}}^{\tilde{M}}$ tells us the difference between two ratios: the fraction of exporters that also import, and the fraction of nonexporters that imports (after partialling out the other elements of $X_{1}$ ). We can now decompose $\delta$ into the contribution of the different elements of $X_{2}$,

$$
\delta_{\tilde{X}}=\underbrace{\Gamma_{\tilde{X}}^{S} \psi_{1}^{S}}_{\delta_{\tilde{X}}^{S}}+\underbrace{\Gamma_{\tilde{X}}^{\tilde{M}} \psi_{1}^{\tilde{M}}}_{\delta_{\tilde{X}}^{\tilde{M}}} .
$$

$\delta_{\tilde{X}}^{S}$ and $\delta_{\tilde{X}}^{\tilde{M}}$ represent, respectively, the part of the exporter unconditional wage premium explained by firm size and import status, respectively. The above parameters are clearly interpretable as the mean exporter-nonexporters gap in firm size or import status, scaled by each covariate's wage-equation impact. These covariate mean differences and wage-equation effects are population parameters that do not depend on the order in which covariates are introduced. Note that if there were no mean differences, for example, in firm size between, say, exporters and nonexporters then the $\Gamma_{\tilde{X}}^{S}$ would be zero. In this case, variation in firm size would explain none of the exporters-nonexporters gap in mean wages. The same would hold if firm size had not effect on wages, so that $\psi_{1}^{S}=0$. As shown in Section 4 this is not the case.

Table 2, using the data described in Section (2), reports the estimates of the models in equation (1) and (2), and of two additional intermediate models $8^{8}$ Column (1) in the Table shows that the unconditional wage premium for exporters is about 19 percent 9 Column (4) shows that, as soon as the importer dummy and firm size are added to the model, the exporter wage premium disappears and actually becomes slightly negative. The change in the exporter wage premium from column (1) to column (4) is very large: 22.2 percentage points. Our goal is to quantify how much of this figure is due to variation in the importer status and how much to variation in the size of the firm. The methodology described above allows us to do so considering only the model in column (1) and the model in column (4), i.e. the base and full models. The standard sequential approach instead requires the estimation of one additional model: either the one in column (2) or the one in column (3). The choice is completely

\footnotetext{
${ }^{8}$ We included in each regression a set of year dummies. Moreover, we used, for comparison purposes, the same sample of 4,272,213 observations that will be used in the main analysis of Section 4 .

${ }^{9}$ Bernard et al. (2007), using 2002 data for the Census of Manufactures, find that the unconditional wage premium for U.S. firms is 17 percent.
} 
arbitrary. Columns (2) and (3) in Table 2 report the estimates of two intermediate models: one only with the importer dummy and one only with firm size. There are two possible sequential approaches, both starting from the model in column (1):

- Sequence 1: the first option is to include the importer dummy first (column 2), interpret the change in the exporter dummy coefficient as due to the conditioning on import status (i.e. 14.7 percent, as reported in Table 3), and then condition on firm size (column 4), and interpret the additional change in the exporter dummy coefficient as due to the presence of the firm size variable (i.e. $22.2-14.7=7.5$ percent).

- Sequence 2: the second option is to include firm size first (column 3), interpret the change in the exporter dummy coefficient as due to the conditioning on firm size (i.e. 16.8 percent), and then condition on the importer dummy (column 4), and interpret the additional change in the exporter dummy coefficient as due to the presence of the importer dummy variable (i.e. $22.2-16.8=5.4$ percent).

Therefore, according to the (arbitrary) choice of either Sequence 1 or Sequence 2, it's either the importer dummy or firm size that matters the most in explaining the change in the exporter wage gap. Panel B in Table 3 summarizes these findings and compares them with the results of the Gelbach (2010) decompositions reported in Panel A. The first row in Panel A reports the estimates of the $\Gamma$ coefficients of the auxiliary regressions of equation (3) and (4). Exporters are much more likely to be importers as well (+59.8 percentage points) than nonexporters $\left(\Gamma_{\tilde{X}}^{\tilde{M}}\right)$ while the mean-size gap between exporters and nonexporters is about 6 workers $\left(\Gamma_{\tilde{X}}^{\tilde{S}}\right)$. The second row in Panel A shows that both being an importer $\left(\psi_{1}^{\tilde{M}}\right)$ and being a larger firm $\left(\psi_{1}^{S}\right)$ has a positive impact on workers' wages. Finally, the third row in Panel A reports the delta coefficients $\delta_{\tilde{X}}^{S}$ (13.8 percent) and $\delta_{\tilde{X}}^{\tilde{M}}$ (8.4 percent), that together sum up to the overall exporter wage gap differential (22.2 percent). Gelbach (2010) decomposition shows the true contribution of the importer status and firm size in explaining the exporter wage gap difference. Both variables play a substantial role. The contribution of each is in-between the two possible results of the sequential approach. However, firm size is responsible for the bigger change (13.8 vs. 8.4 percentage points). As reported in Panel B, the choice of the sequential approach exposes the econometrician to substantially biased results. For example, the role played by firm size can be overstated by 22 percent (Sequence 2) or understated by 46 percent (Sequence 1). These are very large deviations. Applying Gelbach (2010) decomposition we 
can understand the determinants of the change in the exporter status coefficient between any two models and, in particular, we can ask what drives the large bias from using the importersize sequential addition approach. Consider the difference between the estimate of 0.045 in column (2) of Table 2, and column (4) full-specification estimate of -0.030. The difference between these estimates, +0.075 , is the explained-gap component attributed to firm size using the importer-size sequential addition approach. The following projection relationship can help understanding why the firm size component plays a different role when using the sequential approach or Gelbach (2010) conditional decomposition approach:

$$
S=\Gamma_{0}^{S(\tilde{M})}+\tilde{X} \Gamma_{\tilde{X}}^{S(\tilde{M})}+\tilde{M} \Gamma_{\tilde{M}}^{S(\tilde{M})}+\varepsilon^{S(\tilde{M})} .
$$

The $S(\tilde{M})$ superscript notation indicates that the $\Gamma$ parameters come from an equation relating firm size to all the $X_{1}$ variables, as well as the importer dummy. We can therefore use the equivalence result above to show that the difference in the coefficient of the exporter dummy from the specification in column (2) of Table 2 to the specification in column (4) of the same table is

$$
\delta_{\tilde{X}}^{S}(\tilde{M})=\Gamma_{\tilde{X}}^{S(\tilde{M})} \psi_{1}^{S}
$$

We know from above that the estimate of $\delta_{\tilde{X}}^{S}(\tilde{M})$ is equal to +0.075 . We can thus find $\Gamma_{\tilde{X}}^{S(\tilde{M})}$ by dividing $\delta_{\tilde{X}}^{S}(\tilde{M})$ by the Table 2 firm size coefficient in the full specification wage equation, $\psi_{1}^{S}$. The result is $\Gamma_{\tilde{X}}^{S(\tilde{M})}=0.972$. Relative to the conditional decomposition, the bias in $\delta_{\tilde{X}}^{S}(\tilde{M})$ is thus

$$
\operatorname{Bias}^{S(\tilde{M})}=\delta_{\tilde{X}}^{S}(\tilde{M})-\delta_{\tilde{X}}=\left[\Gamma_{\tilde{X}}^{S(\tilde{M})}-\Gamma_{\tilde{X}}^{S}\right] \psi_{1}^{S}=(0.972-1.788) * 0.077=-.063 .
$$

Equation (7) shows that the estimated bias in the part of the explained gap attributed to a covariate depends on two factors. One factor is the difference made by conditioning on importer status when estimating the exporter-nonexporter wage gap, i.e., the difference between $\Gamma_{\tilde{X}}^{S(\tilde{M})}$ and $\Gamma_{\tilde{X}}^{S}$. The other factor that affects the bias from using sequential covariate addition to estimate the firm size share of the explained gap is $\psi_{1}^{S}$, the estimated return to firm size. Using (7) therefore we find that the bias in the contribution of firm size is -0.063 , the same number reported in Panel B of Table 3 . Since the biases in the components attributed to the importer dummy and firm size must sum to zero, it immediately follows that 
the sequential-addition bias in the component attributed to the importer dummy when it is added first to the base specification is equal to $-\operatorname{Bias}^{S(\tilde{M})}$.

In the next Section we apply Gelbach (2010) decomposition to a more complex econometric model. Our aim is to quantify the importance of a set of firm-level and worker-level variables in explaining the exporter and importer wage gaps. While the intuition underlying the decomposition methodology is the same as the one just illustrated, the implementation is considerably more complex due to the presence of a large set of covariates. Fortunately, the methodology is quite flexible. Gelbach (2010) illustrates an easy way to carry out the decomposition. In particular, he shows that it is not necessary to run auxiliary regressions for each covariate in $X_{2}$ but it is possible to group covariates. This proves to be particularly handy in the case $X_{2}$ includes industry and time dummies or worker fixed effects, as it happens below.

\section{Main results}

The main goal of this paper is to assess and compare the effects of exporting and importing in terms of workers' pay. Our analysis is based on the estimation of wage equations with a particularly large set of control variables, including worker fixed effects. The identification of the effects of interest is therefore based on the assumption that, given such large set of controls, variation across observations in trade status is random 10 In this section, we make use of indicators of trade activity that are different from those used in Section 3 ; a set of three dummy variables, indicating whether or not a firm only exports, $X$, whether or not a firm only imports, $M$, and whether or not a firm both exports and imports, $X M$. In Section 3. the goal was to illustrate a new methodology and to make the point that the results in the previous literature, focused only on exporters, can be misleading. In this Section the goal is to quantify the wage gap associated to three different sets of firms, characterized by participation in export markets, import markets, or both.

\footnotetext{
${ }^{10}$ Given the increasing availability of worker-level data and the trend in the literature, we estimates our wage equations only on worker-level data and not on firm-level data. This allows us to address more directly any compositional biases that may explain the firm-level results. For instance, when firms begin importing or exporting they may also adjust their hiring policies towards more skilled employees. Although we can control for several human capital and other variables, such differences in personnel quality over time may still be obscured in the data in such a way that a premium is estimated even if such wage differential can actually be accounted for by worker quality differences. By following each worker over time, we minimize such potential bias.
} 
Specifically, in this subsection we estimate different versions of the following wage equation:

$y_{i j t}=\beta_{1} X_{j(i, t), t}+\beta_{2} M_{j(i, t), t}+\beta_{3} X M_{j(i, t), t}+W_{i j t}^{\prime} \beta_{4}+F_{j(i, t), t}^{\prime} \beta_{5}+I n d_{j(i, t), t}+\operatorname{Reg}_{j(i, t), t}+\eta_{i}+\tau_{t}+\epsilon_{i j t}$,

in which $y_{i j t}$ is logarithm of the real hourly total wage of worker $i$ in firm $j$ in year $t, X_{j(i, t), t}$, $M_{j(i, t), t}$ and $X M_{j(i, t), t}$ are the explanatory variables of interest, dummy variables equal to one if worker $i$ is employed in year $t$ in a firm $j$ that exports only, imports only or exports and imports, respectively ${ }^{11}$ Non-traders (i.e. firms that nor export neither import) are the excluded category. $W_{i j t}$ and $F_{j(i, t), t}$ are vectors of worker and firm control variables. Worker observables include schooling (number of years), a quadratic in experience and in tenure, a gender dummy and the log of hours worked. Firm-level observables include firm size (log of the number of employees), (log) total sales, the number of plants, a foreign ownership dummy, and (log) firm age ${ }^{12} \operatorname{Ind}_{j(i, t), t}$ and $\operatorname{Reg}_{j(i, t), t}$ are a set of 23 industry dummies and 18 regions dummies, respectively. Finally, $\tau_{t}$, and $\eta_{i}$ are time, and worker fixed effects, respectively 13 Table 4 reports the results from estimating equation 8 (the "full model") and a simpler specification that only includes the trade status dummies (the "base model") ${ }^{14}$

Several results are of interest. The first result is that once export and import status are simultaneously controlled for, the unconditional wage premium paid by export-only firms is much smaller than the one usually found in the literature (3.5 percent) while the one paid by firms that also imports is very large (23.9 percent). Firms that both export and import pay their worker a even higher average wage (29.1 percent). As mentioned above, the export status of a firm is a good predictor of its import status Bernard \& Schott (2009), implying that studies that do not control for imports may overestimate the impact of exports. The second result confirms and, to some extent, reinforces a tendency seen in the previous literature: the introduction of firms' and workers' controls explain the almost totality of the unconditional wage premium. In the "full model", the exporter-only wage gap is not

\footnotetext{
${ }^{11}$ Real hourly wages are computed considering all compensation components and diving by the number of regular and overtime hours worked in the reference month. See the Appendix for futher details.

${ }^{12} \mathrm{~A}$ firm is considered foreign-owned if at least 50 percent of its equity is foreign-held.

${ }^{13}$ Note that, since the goal of the analysis is to apply the decomposition outlined in Section 3 , we need to estimate the full set of year, industry, region, and worker fixed effects. While year, industry, and region can potentially be included as dummies, the high dimensionality of the worker fixed effects makes the problem computationally harder. We address this estimation matter by drawing on the algorithm put forward by Guimaraes \& Portugal (2009). See Carneiro et al. (2009) for an application, also based on the QP data set.

${ }^{14}$ Note that the education and gender dummies are omitted from the "full model" (and included in the worker fixed effects) due to insufficient time variation in those characteristics. Both in the "base model" and in the "full model" standard errors are robust, allowing for clustering at the worker level.
} 
significantly different from zero, the importer-only wage gap is significant but very small (0.003), and the exporter-importer wage gap is significant and actually slightly negative (0.004). All other covariates behave as expected: there are positive but diminishing returns for experience and tenure, wages are positively correlated with firm size, sales, foreign ownership, and negatively correlated with firm age. The model fit is pretty high, with an $R^{2}$ equal to 0.92 .

The main result is found by applying the decomposition outlined in Section 3 to the "base" and "full" models of Table 4 . Table 5 reports the results. Unlike in Section 3 , we apply the decomposition to explain the change in the wage gap associated to three variables: the exporter-only (in column 1), importer-only (in column 2), and exporter-importer dummies (in column 3). Instead of reporting the absolute $\delta$ coefficients associated to each type of covariate we report them as a share of the total change in the wage gap when moving from the "base" to the "full" model. The results are striking. The decomposition reveals that the wage premium for workers employed by firms that only export is associated to firms' and workers' characteristics that are very different from those associated to the wage premium for workers employed by firms that also imports. Firms that only export pay higher wages mainly because they are bigger and sell more. The workers that they employ are not, in general, "better" or "more able" than average. Firms that also imports (imports-only or both exports and imports) also pay higher wages because they are bigger and sell more but these factors definitely play a less important role. On the contrary, these firms, and among these those that only imports in particular, decisively employ "better" or "more able" workers. More specifically, in the case of export-only firms, firm-level observables (size, total sales, number of plants, and firm age) account for 80 percent of the wage gap, with the main role played by firm size (32 percent) and firm total sales (40 percent). Firm age also account for 7 percent of the wage gap, with younger firms paying higher wages, while an additional 10 percent of the wage gap is explained by the industry distribution of exporters. Worker-level observables play a substantially smaller role, a total of 7 percent: experience ( 5 percent) has a negative impact on the exporter wage gap. More strikingly, worker fixed effects, capturing all the time-invariant unobserved workers' characteristics, have a limited and negative impact on the exporter wage gap (2 percent).

The picture is quite different for importers 15 Firm-level observables (size, total sales, number

\footnotetext{
${ }^{15}$ For the sake of brevity we focus on the description of the differences between export-only and import-only
} 
of plants, and firm age) are still important but only account for 30 percent of the wage gap, with the main role played by firm size (12 percent) and firm total sales (17 percent). Younger firms still pay higher wages, and the industry distribution of import-only firms is positively related to the wage gap but their role is much smaller (4 percent overall). The main difference lies in the role played by workers' (time-invariant) unobserved characteristics: workers' fixed effects account for a whopping 66 percent of the wage gap. The sign is positive: the wage bill of importers is higher because workers' are on average more able.

As mentioned above, a number of recent papers (e.g. Eaton et al., 2011, Helpman, Itskhoki, and Redding, 2011) have tried to embed a more realistic treatment of labor markets in models of trade with heterogeneous firms. In this respect, our results can provide a guidance for the development of trade theories that model the labor market more "realistically". In Eaton et al. (2011), wages, set through bargaining, are an increasing function of the productivity of the firm. Through bargaining, workers get a share of the profits and therefore a higher wage. Our results are consistent with Eaton et al. (2011) in the sense that we do find that both firms' sales and size are positively associated with a wage premium for exporters. Helpman, Itskhoki, and Redding (2011) propose a trade model with heterogeneous firms and search and matching frictions. More productive firms have large revenues, match with more workers, and screen to higher ability thresholds. As a result they have workforces of higher average ability and pay higher wages. While we also find that firm's size and sales are positively correlated with a wage premium for exporters, we do not find that exporters hire workers that are, on average, more able. Actually, the workers fixed effects in our wage regressions play a slightly negative role in explaining the exporters' wage premium. On the contrary, we find that importers definitely hire workers that have better unobserved time-invariant characteristics. In this respect, our results suggest that the channel suggested by Helpman, Itskhoki, and Redding (2011) seems more adequate to explain the behavior of importers instead of exporters. Overall, a robust result that emerges from this Section is that the hiring policy of exporters is quite different than the one of importers. While firm size and sales, even though to a different extent, are positively related to the wage bill both for exporters and importers, the average ability of the workforce plays a different role: importers definitely have a better workforce, exporters don't. firms, with the understanding that exporter-importers behave similarly to import-only firms. 


\section{Conclusions}

In this paper we investigate the relationship between exporting, importing, and wage premia using a rich matched employer-employee data set from Portugal. We make two main methodological contributions. First, we take into account the importing behavior of firms. Given that the export status of a firm is a good predictor of its import status, firm- or worker-level studies of the link between exports and wages that do not control for imports may overor underestimate the impact of exports. Second, we use a simple methodology introduced in Gelbach (2010) to quantify the importance of firm's observed characteristics, and workers' observed and unobserved time-invariant characteristics in determining the exporters', importers, and exporters-importers' wage premia. The main advantage of this methodology is that it is not sensitive to the order of introduction of the covariates. As shown in Gelbach (2010), the strategy of sequentially adding covariates and interpreting the change in the coefficient of interest as associated to the introduction of each covariate can lead to substantial biases in the results. A robust result that emerges form this paper is that the hiring policy of exporters is quite different than the one of importers. While firm size and sales are, to different extents, important components of the wage gap both for exporters and importers, importers hire workers that are overwhelmingly more able than the average. Workers at exporting firms, on the contrary, are no different in terms of unobserved time-invariant characteristics. Our analysis provides a useful guidance for recent theories that aim at explaining participation both in export and import markets and at including non-neoclassical labor market features.

\section{References}

Altomonte, C. \& Bekes, G. (2009), Trade complexity and productivity, Bocconi University mimeo.

Amador, J. \& Opromolla, L. D. (2008), Product and destination mix in export markets, Working Paper 17-2008, Banco de Portugal.

Amiti, M. \& Davis, D. R. (2008), Trade, firms, and wages: Theory and evidence, NBER Working Paper 14106. 
Amiti, M. \& Konings, J. (2007), 'Trade liberalization, intermediate inputs, and productivity: Evidence from indonesia', American Economic Review 97(5), 1611-1638.

Bernard, A. B. \& Bradford Jensen, J. (1999), 'Exceptional exporter performance: cause, effect, or both?', Journal of International Economics 47(1), 1-25.

Bernard, A. B. \& Jensen, J. B. (1995), 'Exporters, jobs, and wages in U.S. manufacturing: 1976-1987', Brookings Papers on Economic Activity: Microeconomics pp. 67-119.

Bernard, A. B., Jensen, J. B., Redding, S. J. \& Schott, P. K. (2007), 'Firms in international trade', Journal of Economic Perspectives 21(3), 105-130.

Bernard, A., J.-J. \& Schott, P. (2009), chapter Importers, Exporters and Multinationals: A Portrait of Firms in the U.S. that Trade Goods.

Blanchard, O. \& Portugal, P. (2001), 'What hides behind an unemployment rate: Comparing portuguese and u.s. labor markets', American Economic Review 91(1), 187-207.

Cabral, L. \& Mata, J. (2003), 'On the evolution of the firm size distribution: Facts and theory', American Economic Review 93(4), 1075-1090.

Cardoso, A. \& Portugal, P. (2005), 'Contractual wages and the wage cushion under different bargaining settings', Journal of Labor Economics 23(4), 875-902.

Carneiro, A., Guimaraes, P. \& Portugal, P. (2009), Real wages and the business cycle: Accounting for worker and firm heterogeneity, IZA Discussion Papers 4174.

Clerides, S. K., Lach, S. \& Tybout, J. R. (1998), 'Is learning by exporting important? Microdynamic evidence from Colombia, Mexico, and Morocco', Quarterly Journal of Economics $\mathbf{1 1 3}(2), 903-947$.

Davidson, C., Matusz, S. J. \& Shevchenko, A. (2008), 'Globalization and firm level adjustment with imperfect labor markets', Journal of International Economics 75(2), 295-309.

De Loecker, J. (2007), 'Do exports generate higher productivity? Evidence from Slovenia', Journal of International Economics 73(1), 69-98.

Eaton, J., Kortum, S. \& Kramarz, F. (2004), 'Dissecting trade: Firms, industries, and export destinations', American Economic Review Papers and Proceedings 94(2), 150-154. 
Eaton, J., Kortum, S., Kramarz, F. \& Sampognaro, R. (2011), Dissecting the french export wage premium, Penn State University mimeo.

Egger, H. \& Kreickemeier, U. (2009), 'Firm heterogeneity and the labor market effects of trade liberalization', International Economic Review 50(1), 187-216.

Felbermayr, G., Prat, J. \& Schmerer, H.-J. (2011), 'Globalization and labor market outcomes: Wage bargaining, search frictions, and firm heterogeneity', Journal of Economic Theory 146(1), 39-73.

Fillat, J. L. \& Garetto, S. (2009), 'Risk, returns, and multinational production', (mimeo).

Freeman, R. B. (1995), 'Are your wages set in Beijing?', Journal of Economic Perspectives 9(3), 15-32.

Frias, J. A., Kaplanz, D. S. \& Verhoogen, E. A. (2009), Exports and wage premia: Evidence from Mexican employer-employee data, Columbia University mimeo.

Gelbach, J. B. (2010), When do covariates matter? and which ones, and how much?, University of Arizona mimeo.

Goldberg, P. K., Khandelwal, A., Pavcnik, N. \& Topalova, P. (2008), Imported intermediate inputs and domestic product growth: Evidence from India, NBER Working Paper 14416.

Guimaraes, P. \& Portugal, P. (2009), A simple feasible alternative procedure to estimate models with high-dimensional fixed effects, IZA Discussion Paper 3935.

Halpern, L., Koren, M. \& Szeidl, A. (2009), Imports and productivity, University of California, Berkeley mimeo.

Helpman, E., Itskhoki, O. \& Redding, S. (2011), Trade and labor market outcomes, NBER Working Paper 16662.

Hummels, D., Jorgensen, R., Munch, J. \& Xiang, C. (2010), The wage and employment effects of outsourcing: Evidence from Danish matched worker-firm data, Purdue University mimeo.

Iacovone, L. \& Javorcik, B. (2008), Multi-product exporters: Diversification and micro-level dynamics, World Bank Working Paper 4723. 
Irarrazabal, A., Moxnes, A. \& Opromolla, L. D. (2010), The margins of multinational production and the role of intra-firm trade, CEPR Discussion Paper 7145.

Kasahara, H. \& Rodrigue, J. (2008), 'Does the use of imported intermediates increase productivity? Plant-level evidence', Journal of Development Economics 87(1), 106-118.

Kramarz, F. (2008), Offshoring, wages, and employment: Evidence from data matching imports, firms, and workers, CREST-INSEE mimeo.

Krugman, P. (1994), Competitiveness: Does it matter?, Fortune magazine.

Krugman, P. (2008), Trade and wages, reconsidered, Brookings Papers on Economic Activity.

Martins, P. S. (2009), 'Dismissals for cause: The difference that just eight paragraphs can make', Journal of Labor Economics 27(2), 257-279.

Melitz, M. J. (2003), 'The impact of trade on intra-industry reallocations and aggregate industry productivity', Econometrica 71(6), 1695-1725.

Mitra, D. \& Ranjan, P. (2010), 'Offshoring and unemployment: The role of search frictions and labor mobility', Journal of International Economics 81(2), 219-229.

Moxnes, A., Irarrazabal, A. \& Ulltveit-Moe, K. H. (2010), Heterogeneous firms or heterogeneous workers? implications for exporter premia and the gains from trade, Dartmouth College mimeo.

Munch, J. R. \& Skaksen, J. R. (2008), 'Human capital and wages in exporting firms', Journal of International Economics 75(2), 363-372.

Muuls, M. \& Pisu, M. (2009), 'Imports and exports at the level of the firm: Evidence from belgium', The World Economy 32(5), 692-734.

Schank, T., Schnabel, C. \& Wagner, J. (2007), 'Do exporters really pay higher wages? First evidence from German linked employer-employee data', Journal of International Economics 72(1), $52-74$.

Van Biesebroeck, J. (2005), 'Exporting raises productivity in sub-Saharan African manufacturing plants', Journal of International Economics 67(2), 373-391. 
Verhoogen, E. A. (2008), 'Trade, quality upgrading, and wage inequality in the Mexican manufacturing sector', Quarterly Journal of Economics 123(2), 489-530.

\section{Appendix: Data}

\section{A. INE trade data}

The INE trade data include all export and import transactions by firms that are located in Portugal, on a monthly basis. These data are derived from customs returns forms in the case of extra-EU trade and from a special form supplied to the Portuguese statistics agency, INE Instituto Nacional de Estatistica (Intrastat) in the case of intra-EU trade. Firms are required to provide information on their trade transactions if the volume of exports or imports in the previous year or two years before was higher than 60,000 euros and 85,000 euros respectively. Overall, the data amount to the official total exports and imports of Portugal.

Each transaction record includes the firm tax identifier, an eight digit Combined Nomenclature product code, the value of the transaction, the quantity of transacted goods (expressed in kilograms), the destination/origin country, the type of transport, the relevant international commercial term (FOB, CIF, etc) and a variable indicating the type of transaction (transfer of ownership after payment, return of a product, etc). Also see Amador \& Opromolla (2008) for more information about the data and several descriptive statistics.

\section{B. QP labor data}

Quadros de Pessoal (QP), a longitudinal dataset matching firms and workers based in Portugal. The data are made available by the Ministry of labor and Social Security, drawing on a compulsory annual census of all firms in Portugal that employ at least one worker. The Ministry of labor and Social Security has been conducting this survey since 1982 and the employment and wage data refer to the month of October since 1994. In our analysis we use information for the period 1995 until 2005. The data also cover individual information on all personnel working for each firm in the reference month, except for 2001.

The administrative nature of the data and their public availability at the workplace as required by law - imply a high degree of coverage and reliability. Our sample includes all manufacturing firms based in Continental Portugal and their full-time employees, age between 16 and 65 , working a minimum of 25 and a maximum of 80 total hours per week.

The variables available in the data set include the firm's location, industry, total employment, sales, ownership structure (foreign, domestic private and domestic public), and legal setting. At the worker's level, the data set includes information on gender, age, occupation, schooling, hiring date, earnings (five different variables), duration of work (three different variables), as well as information about collective bargaining.

The mean wage is computed adding base and overtime wages plus tenure- and performancerelated compensation and dividing by the number of regular and overtime hours worked in the reference month. Sales, exports and imports are expressed in 2004 billion euros. Gross wages are deflated by the Consumers Price Index (made available by INE) to 2004 euros.

We classify firms as foreign-owned if they have a foreign participation in their equity of at least 50 percent. 78 percent of the firms in our sample with a non-zero foreign ownership meet this threshold.

Personnel on short-term leave (such as sickness, maternity, strike or holidays) are included, whereas personnel on long-term leave (such as military service) are not reported. Civil ser- 
vants, the self-employed and domestic service are not covered, and the coverage of agriculture is low given its low share of wage-earners.

\section{Theoretical discussion}

There are two main theoretical views one can appeal to in order to interpret any wage differences, in particular those among exporters, importers and non-traders, which we study in this paper. In the first case, competitive views of the labor market would regard any wage premiums as a reflection of worker (unobserved) quality. For instance, econometric studies may draw on less information on workers than that available to employers when hiring, retaining or dismissing employees. In this case the wage premiums could correspond to systematic differences between the workforces in different types of firms and not to wages above the outside options of workers.

Similarly, wage differences could correspond to compensating differentials, for instance if the working conditions of firms that trade were disadvantageous compared to those of firms that do not trade. As an example, international traders may be subject to greater risk in terms of customer orders or production conditions, in which case workers would demand premiums ${ }^{16}$ Alternatively, international traders may be able to achieve less risk through international diversification in their input and/or output markets, in which case workers would be willing to be paid less.

A second main theoretical view involves non-competitive mechanisms in the labor market. These typically evolve from search frictions or informational imperfections, for instance in terms of the matching between job-seekers and vacancies or in terms of the monitoring of worker effort. In the case of efficiency wages, firms that trade may require higher effort from their workers (see Verhoogen (2008) for the case of exporters). One example would be if consumers in destination countries value quality more than in the origin country. Firms that wish to export will then have to adjust the quality of their product mix and to motivate workers to exert more effort - for instance through wages that are sufficiently higher than the worker's best alternative 17

An alternative non-competitive mechanism that would generate a wage premium is rent sharing. In an important contribution, Kramarz (2008) emphasizes that importing can affect wages both because it changes the overall quasi-rent but also because it can affect the firms and the workers threat points when bargaining. There are a number of reasons why these threat points may change: for instance, imports of intermediate products may provide workers with hold-up opportunities when the firm has to purchase these inputs in advance. This might explain why importers pay more than non-importers (including exporters-only). However, imports of finished goods by the firm or by its competitors may weaken the employees' bargaining position if these imports result in a decrease of the workers' outside offers. Moreover, exporters may also need to make specific investments that would generate hold-up opportunities for their workers 18

\footnotetext{
${ }^{16}$ For example, Fillat \& Garetto (2009) show that exporters tend to have higher earning yields and returns than firms selling only in their domestic market. They develop a real option value model where firms are heterogeneous in terms of productivity to show that exporters (and, even more, multinationals) are more exposed to risk because of the sunk costs that they paid to enter the foreign market.

${ }^{17}$ Moreover, firms that want to export might need to update their equipment and import better machines from abroad (Iacovone \& Javorcik (2008) show that the introduction of new export products tends to be preceded by investment in physical assets and technology acquisition). These firms might pay workers even more because the marginal benefit of convincing workers to exert more effort is higher due to the interaction of workers' effort with better machines.

${ }^{18}$ See also Amiti \& Davis (2008) who consider a model with fair wages, another non-competitive mechanism, where wages in the firm are proportional to firm's profits and not necessarily equal to the worker's outside option; and Davidson et al. (2008).
} 
A related point is that firms that trade may face different elasticities of demand of the products they sell. In particular, the elasticity of demand with respect to the product price may be higher for exporters than for non-exporters to the extent that the international market is more competitive than the domestic market. In this case, as indicated by Marshall's rules, exporters will be less prone to concede wage premia than importers. Taking one step further, the level of competition faced by exporters may depend on the technological content of the product (or variety within a product) that they sell. Firms that are able to sell high technology goods may be able to enter into markets with higher product differentiation and a lower degree of competition. As a consequence they might be able to secure higher rents that could be partially passed on to their workers. Similarly, firms that are able to improve the quality of their products by using better (higher quality and/or cheaper) intermediate inputs or machines might be able to better face competition in international markets as well as on the domestic market.

The non-competitive models have a strong potential explanatory power given the evidence that exporters are more productive than firms that sell only on the domestic market. ${ }^{19}$ In this case, exporters gain higher profits than non-exporters and might pass on some of those gains to their workers through some form of rent sharing.

Moreover, recent research on the productivity effects from international trade is placing emphasis on the role of importing too. To begin with, exporters are frequently importers as well Bernard \& Schott (2009), in which case part of the productivity advantage of exporters can be due to their sourcing inputs from foreign markets Altomonte \& Bekes (2009). In any case, either that of importers only or exporter-importers, access to cheaper imported inputs can again raise productivity via learning, variety, and quality effects Amiti \& Konings (2007), Kasahara \& Rodrigue (2008), Goldberg et al. (2008), Halpern et al. (2009). Importers arguably have greater choice in the sourcing of their inputs and can exploit any gaps between international and national prices, resulting in productivity or cost-efficiency differences.

Having reviewed the explanations above for either true or spurious wage premiums among importers and exporters when compared to non-traders, we underline that most if not all arguments apply equally to importers and exporters. However, the intensity of any worker heterogeneity or productivity effects may still vary depending on the specific trade status of the firm. In particular, importing and exporting may enhance a firm's profitability differently, particularly when products of different technological level are being transacted.

\footnotetext{
${ }^{19}$ Some research has argued that exporters are ex-ante more efficient and, as such, are able to sustain fixed and variable trade costs and self-select into export markets Clerides et al. (1998), Bernard \& Bradford Jensen (1999). Other studies have shown that, on top of self-selection, exporters might become more productive because they learn from exporting Van Biesebroeck (2005), especially when goods are sold to high-income countries De Loecker (2007).
} 


\section{Tables}

Table 1: Descriptive Statistics, Pooled 1995-2005 Data

Panel A: Firm-level description

\begin{tabular}{lcccccccc} 
& \multicolumn{3}{c}{ Non-Trading Firms } & \multicolumn{3}{c}{ Exporters-only } \\
& Mean & Med. & S.D. & Obs. & Mean & Med. & S.D. & Obs. \\
\hline Sales & 507.97 & 218.61 & 3313.44 & 149,791 & 1335.55 & 703.28 & 5177.92 & 17,105 \\
Size & 12.71 & 8.00 & 20.47 & 149,791 & 25.97 & 18.00 & 29.26 & 17,105 \\
Foreign (0/1) & 0.00 & 0.00 & 0.06 & 149,791 & 0.01 & 0.00 & 0.10 & 17,105 \\
\# Plants & 1.14 & 1.00 & 1.55 & 149,791 & 1.11 & 1.00 & 1.21 & 17,105 \\
Firm Age & 13.27 & 10.00 & 12.05 & 149,791 & 17.32 & 14.00 & 14.63 & 17,105 \\
& \multicolumn{4}{c}{ Importers-only } \\
\hline Sales & 3348.86 & 1282.65 & 11200.00 & 18,867 & \multicolumn{5}{c}{ Exporters-Importers } \\
Size & 35.23 & 20.00 & 61.62 & 18,867 & 111.34 & 57.00 & 208.12 & 28,553 \\
Foreign (0/1) & 0.04 & 0.00 & 0.20 & 18,867 & 0.11 & 0.00 & 0.31 & 28,553 \\
\# Plants & 1.29 & 1.00 & 1.54 & 18,867 & 1.41 & 1.00 & 2.05 & 28,553 \\
Firm Age & 17.93 & 15.00 & 14.29 & 18,867 & 22.83 & 19.00 & 18.11 & 28,553 \\
\hline
\end{tabular}

Panel B: Worker-level description

\begin{tabular}{lcccccccc} 
& \multicolumn{3}{c}{ Non-Trading Firms } & \multicolumn{3}{c}{ Exporters-only } \\
& Mean & Med. & S.D. & Obs. & Mean & Med. & S.D. & Obs. \\
\hline Schooling & 6.04 & 6.00 & 2.80 & $1,170,610$ & 5.93 & 4.00 & 2.89 & 295,577 \\
Experience & 24.86 & 23.00 & 12.02 & $1,170,610$ & 25.29 & 24.00 & 11.99 & 295,577 \\
Tenure & 7.48 & 5.00 & 7.84 & $1,170,610$ & 8.96 & 7.00 & 8.51 & 295,577 \\
Female (0/1) & 0.42 & 0.00 & 0.49 & $1,170,610$ & 0.49 & 0.00 & 0.50 & 295,577 \\
Hours Worked & 39.90 & 39.92 & 2.54 & $1,170,610$ & 39.86 & 39.92 & 2.44 & 295,577 \\
Hourly Wage & 3.64 & 3.01 & 2.09 & $1,170,610$ & 3.76 & 3.09 & 2.16 & 295,577 \\
& & Importers-only & & \multicolumn{4}{c}{ Exporters-Importers } \\
\hline Schooling & 6.82 & 6.00 & 3.54 & 473,718 & 6.86 & 6.00 & 3.54 & $2,332,308$ \\
Experience & 24.88 & 24.00 & 12.05 & 473,718 & 25.10 & 24.00 & 12.06 & $2,332,308$ \\
Tenure & 9.70 & 7.00 & 8.90 & 473,718 & 11.81 & 9.00 & 9.87 & $2,332,308$ \\
Female (0/1) & 0.36 & 0.00 & 0.48 & 473,718 & 0.43 & 0.00 & 0.50 & $2,332,308$ \\
Hours Worked & 39.97 & 39.92 & 2.91 & 473,718 & 40.25 & 39.92 & 2.96 & $2,332,308$ \\
Hourly Wage & 4.86 & 3.74 & 3.39 & 473,718 & 5.12 & 3.99 & 3.48 & $2,332,308$ \\
\hline \hline
\end{tabular}

Notes: Panel A presents summary statistics of firm-level variables while Panel B presents summary statistics of worker-level variables. Summary statistics are computed pooling the data for the 1995-2005 period. Sales are expressed in thousands euro. Firm age, schooling, experience, and tenure are expressed in number of years. The hourly wage is in euro. The column "Obs." lists the number of firm-year observations in Panel A and the number of worker-year observations in Panel B. See the data appendix for variable definitions. 
Table 2: A Simple Example of Sequence-sensitivity: Exporter Wage Premium, Importer Status, and Size

\begin{tabular}{|c|c|c|c|c|}
\hline & $(1)$ & $(2)$ & (3) & (4) \\
\hline Coefficient on Exporter $\tilde{X}$ & $\begin{array}{c}0.193^{* * *} \\
(0.000)\end{array}$ & $\begin{array}{c}0.045^{* * *} \\
(0.001)\end{array}$ & $\begin{array}{c}0.024^{* * *} \\
(0.001)\end{array}$ & $\begin{array}{c}-0.030^{* * *} \\
(0.001)\end{array}$ \\
\hline Coefficient on Importer $\tilde{M}$ & & $\begin{array}{c}0.246^{* * *} \\
(0.001)\end{array}$ & & $\begin{array}{c}0.141^{* * *} \\
(0.001)\end{array}$ \\
\hline Coefficient on Firm Size S & & & $\begin{array}{c}0.094^{* * *} \\
(0.001)\end{array}$ & $\begin{array}{c}0.077^{* * *} \\
(0.000)\end{array}$ \\
\hline \multicolumn{5}{|l|}{ Included covariates } \\
\hline Importer $\tilde{M}(0 / 1)$ & $\mathrm{N}$ & $\mathrm{Y}$ & $\mathrm{N}$ & $\mathrm{Y}$ \\
\hline Firm Size (log) & $\mathrm{N}$ & $\mathrm{N}$ & $\mathrm{Y}$ & $\mathrm{Y}$ \\
\hline
\end{tabular}

Notes: All equations include year dummies and are estimated on the same sample of 4,272,213 observations used in Section 4 . Robust standard errors in parentheses, allowing for clustering at the worker level. Significance levels: *** 1 percent; ${ }^{* *} 5$ percent; * 10 percent. 
Table 3: Understanding the Decomposition of $\hat{\delta}_{\tilde{X}}$

Panel A: Conditional Decomposition Components

\begin{tabular}{lccc} 
& Importer $\tilde{M}$ & Firm Size $S$ & Total \\
\hline$\hat{\Gamma}_{\tilde{X}}$ & 0.598 & 1.788 & \\
$\psi_{1}$ & 0.141 & 0.077 & \\
$\hat{\delta}_{\tilde{X}}\left(=\hat{\Gamma}_{\tilde{X}} \times \psi_{1}\right)$ & 0.084 & 0.138 & 0.222 \\
\hline
\end{tabular}

Panel B: Sequential Decomposition Components

\begin{tabular}{lccc} 
& Importer $\tilde{M}$ & Firm Size $S$ & Total \\
\hline Sequence 1: Importer-Size & & & \\
Explained gap & 0.147 & 0.075 & 0.222 \\
Bias & 0.063 & -0.063 & 0.000 \\
& & & \\
Sequence 2: Size-Importer & & & \\
Explained gap & 0.054 & 0.168 & 0.222 \\
Bias & -0.084 & +0.084 & 0.000 \\
\hline
\end{tabular}

Notes: Panel A reports the estimated coefficients from the auxiliary regressions of equations (3) and (4) (in the first row), the estimated coefficients of the importer dummy and firm size in the full model of equation (1) (second row), and their product (third row). The latter represents the contribution of each of the two covariates in explaining the wage gap according to the methodology described in Section 3 Panel B reports the contribution ("explained gap") of the importer dummy and firm size in explaining the wage gap according to the sequential approach. "Sequence 1" denotes the case in which the importer dummy is introduced first and firm size second. "Sequence 2" denotes the opposite case. "Bias" represents the difference, for each covariate, in the contribution according to the two methodologies. 
Table 4: Trade status wage premia - base and full model

\begin{tabular}{|c|c|c|c|}
\hline & Base Model & Full Model & Difference \\
\hline Exporter only $X$ & $\begin{array}{c}0.035^{* * *} \\
(0.001)\end{array}$ & $\begin{array}{c}.001 \\
(0.001)\end{array}$ & $-97 \%$ \\
\hline Importer only $M$ & $\begin{array}{c}0.239^{* * *} \\
(0.001)\end{array}$ & $\begin{array}{c}.003^{* * *} \\
(0.001)\end{array}$ & $-99 \%$ \\
\hline Exporter-Importer $X M$ & $\begin{array}{c}0.291^{* * *} \\
(0.001)\end{array}$ & $\begin{array}{c}-0.004^{* * *} \\
(0.001)\end{array}$ & $-102 \%$ \\
\hline Experience & & $\begin{array}{c}0.008^{* * *} \\
(0.000)\end{array}$ & \\
\hline Experience $^{2}$ & & $\begin{array}{c}-0.026^{* * *} \\
(0.000)\end{array}$ & \\
\hline Tenure & & $\begin{array}{c}0.003^{* * *} \\
(0.000)\end{array}$ & \\
\hline Tenure $^{2}$ & & $\begin{array}{c}-0.012^{* * *} \\
(0.000)\end{array}$ & \\
\hline Hours Worked $(\ln )$ & & $\begin{array}{c}-0.192^{* * *} \\
(0.003)\end{array}$ & \\
\hline Firm Size (ln) & & $\begin{array}{c}0.027^{* * *} \\
(0.001)\end{array}$ & \\
\hline \# Plants & & $\begin{array}{c}-0.001^{* * *} \\
(0.000)\end{array}$ & \\
\hline Foreign Ownership (0/1) & & $\begin{array}{c}0.029^{* * *} \\
(0.001)\end{array}$ & \\
\hline Firm Age (ln) & & $\begin{array}{c}-0.010^{* * *} \\
(0.000)\end{array}$ & \\
\hline Total Sales (ln) & & $\begin{array}{c}0.021^{* * *} \\
(0.000)\end{array}$ & \\
\hline Obs. & $4,272,213$ & $4,272,213$ & \\
\hline$R^{2}$ & 0.096 & 0.923 & \\
\hline
\end{tabular}

Notes: Both the base and full models include year fixed effects. The full model also includes: worker controls (schooling, a quadratic in experience and in tenure, a gender dummy and the log of hours), firm controls (log of number of employees, the number of establishments, and a foreign ownership dummy), a set of 18 region, and 23 industry dummies. The education and gender dummies are omitted (and included in the worker fixed effects) due to insufficient time variation in those characteristics. Robust standard errors, allowing for clustering at the worker level. Significance levels: *** 1 percent; ** 5 percent; ${ }^{*} 10$ percent. 
Table 5: Trade status wage premia - Decomposition

\begin{tabular}{|c|c|c|c|}
\hline & Export-only $\mathrm{X}$ & Import-only Y & Export-import XM \\
\hline \multicolumn{4}{|c|}{ Worker characteristics } \\
\hline \multicolumn{4}{|l|}{ Observables } \\
\hline Experience & $-0.06^{* * *}$ & 0.00 & $-0.01^{* * *}$ \\
\hline Tenure & $0.03^{* * *}$ & $0.00^{* * *}$ & $0.00^{* * *}$ \\
\hline Hours & $0.01^{* * *}$ & $0.00^{* * *}$ & $0.00^{* * *}$ \\
\hline \multicolumn{4}{|l|}{ Unobservables } \\
\hline Worker Fixed Effect & -0.02 & $0.69^{* * *}$ & $0.52^{* * *}$ \\
\hline \multicolumn{4}{|c|}{ Firm characteristics } \\
\hline Firm Size & $0.45^{* * *}$ & $0.12^{* * *}$ & $0.21^{* * *}$ \\
\hline Sales & $0.55^{* * *}$ & $0.17^{* * *}$ & $0.24^{* * *}$ \\
\hline \# Plants & $0.01^{* * *}$ & $0.00^{* * *}$ & $0.00^{* * *}$ \\
\hline Foreign & $0.01^{* * *}$ & $0.01^{* * *}$ & $0.02^{* * *}$ \\
\hline Firm Age & $-0.09^{* * *}$ & $-0.02^{* * *}$ & $-0.02^{* * *}$ \\
\hline \multicolumn{4}{|c|}{ Other } \\
\hline Region & $-0.01^{* * *}$ & $0.01^{* * *}$ & $0.00^{* * *}$ \\
\hline Industry & $0.14^{* * *}$ & $0.02^{* * *}$ & $0.03^{* * *}$ \\
\hline Year & $0.00^{* * *}$ & $0.00^{* * *}$ & $0.00^{* * *}$ \\
\hline Total & 1 & 1 & 1 \\
\hline
\end{tabular}

Notes: Decomposition of the difference between the X (Y, XM) coefficients in the base and full model of Table 4 according to the methodology presented in Section 3 Robust standard errors, allowing for clustering at the worker level. Significance levels: *** 1 percent; ${ }^{* *} 5$ percent; ${ }^{*} 10$ percent. 